Annals of Warsaw University of Life Sciences - SGGW

Land Reclamation No 50 (1), 2018: 55-67

(Ann. Warsaw Univ. of Life Sci. - SGGW, Land Reclam. 50 (1), 2018)

\title{
Strength and deformation parameters of boulder clay to design of buildings at the margin of a moraine plateau in Warsaw
}

\author{
SIMON RABARIJOELY, KAZIMIERZ GARBULEWSKI \\ Faculty of Civil and Environmental Engineering, Warsaw University of Life Sciences - SGGW
}

\begin{abstract}
Strength and deformation parameters of boulder clay to design of buildings at the margin of a moraine plateau in Warsaw. The selection of soil parameters suitable to the geotechnical design calculations is regarded widely as one of the most important and simultaneously difficult engineering task, which according to the Eurocode 7 standards should be undertaken into distinct three steps. The second of these steps, namely obtaining the characteristic values requires a careful and a cautions estimation with application of the statistical methods even by using a Bayesian approach as shown in this paper. This paper presents the process of selecting a characteristic strength and deformation parameters from CPT and DMT investigation for boulder clays discovered at the margin of a moraine plateau in Warsaw. This layer was chosen for foundations of design academic buildings. In the selection of the characteristic parameters with application of the numerical program BAYANAL the spatial distribution of strength and deformation properties was taken into account. Particular attention was focused to the affect resulting from in situ test locations at different distances from the design facilities. Finally, the remark conclusions were presented including opinion on the role of aims and spacing of investigation points in geotechnical designing.
\end{abstract}

Key words: design clay parameters, statistical analysis, Bayesian approach, geotechnical design, Eurocode 7

\section{INTRODUCTION}

In geotechnical design with respect to rules and principles of the Eurocode 7 (EN 1997-1:2004, EN 1997-2:2004) the step selection of geotechnical actions and resistances (Fig. 1), particularly characteristic material parameters, is considered as a crucial process creating the difficulties for designers. For selecting characteristic values of geotechnical parameters (step 2) the statistical methods are commonly recommended (Frank et al. 2004, Pieczyrak 2009, Schuppener et al. 2009, Popielski and Dąbska 2012). The results of this step is affected by many factors, e.g. the uncertainty parameters that can be derived from natural variability, measurement errors and statistical uncertainty. In the classic statistics, based on a random sample drawn from the population, to determine the average value and standard deviation value with the required confidence level (e.g. 95\%) a finite set of values derived from geotechnical parameters population is assumed. In this approach the parameters' values are particular though not known. If we are dealing with a homogeneous medium (ground), to determine the characteristic values of geotechnical parameters $\left(X_{k}\right)$ the Student's t-95 percent confidence level can be used according to the formula:

$X_{k}=X_{m}\left[1-k_{n} V_{x}\right]$

where:

$X_{m}$ - average of soil parameter;

$k_{n}$ - statistical factor;

$V_{x}-$ coefficient of variation. 


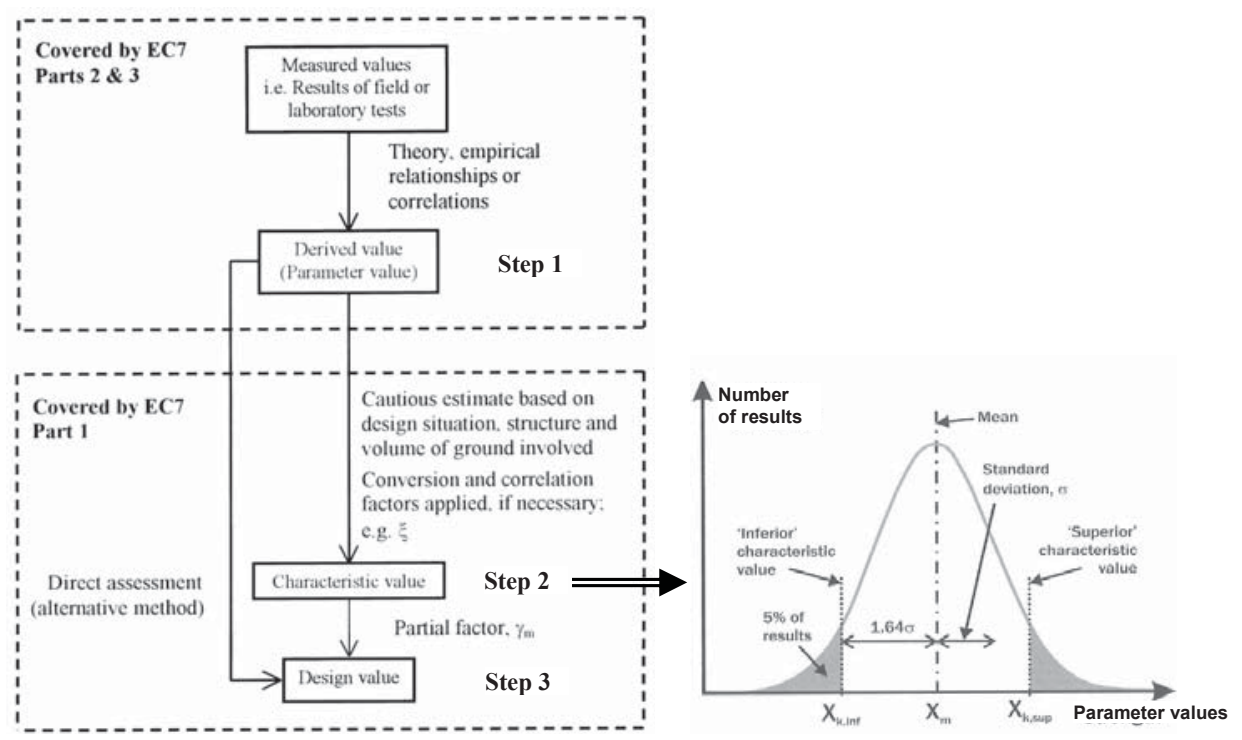

FIGURE 1. Process for obtaining design parameter values from test results Source: own elaboration on the basis of ORR (2005), Bond and Harris (2008), Garbulewski et al. (2009)

Schneider (1990, 1997, 2010) and Schneider and Fitze (2009) proposed to assume $k_{n}=0.5$, it means one half a standard deviation below the mean value.

In an alternative approach, derived from the Bayes theorem (Alén 1998, Alén and Sällfors 1999, Uzielli 2008), deduction can be based not only on a random sample but also on so-called a priori information. To determine the characteristic values, e.g. strength and deformation of soils, it is proposed to use Bayesian analysis, in which there is possible to continue data collection parameters derived according to the following formula:

$$
f(\theta \mid x)=\frac{f(x \mid \theta) \cdot f(\theta)}{\int_{\Omega} f(x \mid \theta) \cdot f(\theta) d \theta}
$$

where:

$f(\theta \mid x)$ - the posterior density function of $\theta$ parameter, after the sample's result $x$ has been observed;

$f(\theta)$ - a priori distribution density function of $\theta$ parameter;

$f(x \mid \theta)$ - credible function i.e. density function of conditional observation's result $x$ with given value of $\theta$;

$\Omega$ - the set of $\theta$ parameter's possible values.

The presented Bayes theorem gives a valuable practical possibility of successive including of new information, coming from consecutively drawn random samples.

The design values of the actions and the combination of the actions defined in Eurocode 7 (design approaches DA1, DA2 and DA3) can be obtained introducing partial factors $\gamma$ for the actions and factors $\psi$ for the accompanying vari- 
able actions. According to National Annex for spread foundation in Poland the design approach DA2* should be used. Applying approach DA2* to the geotechnical actions and simultaneously to the other actions on/from the design structure characteristic values of geotechnical parameters can be used. In case of eccentric loading the design parameters are recommended for obtaining the total ground resistance. Recommended values for partial factors of action and resistance are presented in Table 1. Verification for ultimate limit state require to check the inequality:

$E_{d, d s t} \leq E_{d, s t}+R_{d}$

or utilization factor:

$\Lambda_{G E O}=E_{d, d s t} /\left(E_{d, s t}+R_{d}\right)$

where:

$E_{d, d s t}$ - the design effect of destabilizing actions;
$E_{d, s t}$ - the design effect of stabilizing actions;

$R_{d}$ - any design resistance that helps to stabilize the structure.

Design is unacceptable if utilization factor $\Lambda_{G E O}>100 \%$.

The paper addresses the applicability of the Bayesian approach to determine a characteristic parameters of boulder clays ingeotechnical design of the WULS-SGGW Campus in Warsaw. The selection of the geotechnical characteristic parameters was carried out using the new numerical code called BAYANAL. Overview of BAYANAL code, its assumption and requirement and procedure of statistical analysis had been presented. In order to document the impact of in situ test localization the design calculations for selection of characteristic parameters for boulder clay layer in design building on the WULS-SGGW Campus were car-

TABLE 1. Recommended values for partial factors (set for DA2*) according to EN 1997-1:2004

\begin{tabular}{|c|c|c|c|c|c|c|}
\hline \multirow{2}{*}{\multicolumn{2}{|c|}{ Parameter }} & \multirow{3}{*}{$\begin{array}{c}\text { Symbol } \\
\qquad \gamma_{G, \mathrm{dst}}\end{array}$} & \multirow{3}{*}{$\begin{array}{c}E Q U \\
1.1 \\
\end{array}$} & \multicolumn{3}{|c|}{$G E O / S T R$ - partial factor set } \\
\hline & & & & \multirow{2}{*}{$\begin{array}{c}\mathrm{A} 1 \\
1.35\end{array}$} & \multirow[t]{2}{*}{ M1 } & \multirow[t]{2}{*}{$\mathrm{R} 2$} \\
\hline \multirow{2}{*}{ Permanent action $(G)$} & unfavourable & & & & & \\
\hline & favourable & $\gamma_{G, \mathrm{stb}}$ & 0.9 & 1.0 & & \\
\hline \multirow{2}{*}{ Variable action $(Q)$} & unfavourable & $\gamma_{Q, \mathrm{dst}}$ & 1.5 & 1.5 & & \\
\hline & favourable & - & - & - & & \\
\hline \multirow{2}{*}{ Accidental action $(A)$} & unfavourable & $\gamma_{A, \mathrm{dst}}$ & 1.0 & 1.0 & & \\
\hline & favourable & - & - & - & & \\
\hline \multicolumn{2}{|c|}{ Coefficient of shearing resistance $\left(\tan \varphi^{\prime}\right)$} & $\gamma_{\varphi^{\prime}}$ & 1.25 & & 1.0 & \\
\hline \multicolumn{2}{|l|}{ Effective cohesion $\left(c^{\prime}\right)$} & $\gamma_{c^{\prime}}$ & 1.25 & & 1.0 & \\
\hline \multicolumn{2}{|c|}{ Undrained shear strength $\left(c_{u}\right)$} & $\gamma_{c u}$ & 1.4 & & 1.0 & \\
\hline \multicolumn{2}{|c|}{ Unconfined compressive strength $\left(q_{u}\right)$} & $\gamma_{q u}$ & 1.4 & & 1.0 & \\
\hline \multicolumn{2}{|l|}{ Weight density $(\gamma)$} & $\gamma_{\gamma}$ & 1.0 & & 1.0 & \\
\hline \multicolumn{2}{|l|}{ Bearing resistance $\left(R_{v}\right)$} & $\gamma_{R v}$ & & & & 1.4 \\
\hline \multicolumn{2}{|l|}{ Sliding resistance $\left(R_{h}\right)$} & $\gamma_{R h}$ & & & & 1.1 \\
\hline \multicolumn{2}{|l|}{ Earth resistance $\left(R_{h}\right)$} & $\gamma_{R e}$ & & & & 1.4 \\
\hline \multicolumn{2}{|l|}{ Design Approach 2} & \multicolumn{5}{|c|}{$(\mathrm{A} 1+\mathrm{M} 1+\mathrm{R} 2)$} \\
\hline
\end{tabular}


ried out. Finally, the code application in evaluation of characteristic and design parameters (strength and deformation) for boulder clay was describe. The design values of clay strength parameters were applied to determine the foundation dimensions of academic Building 34.

\section{BAYANAL CODE - ASSUMPTIONS AND REQUIREMENT}

The basic assumptions and requirements for the BAYANAL code application are as follows: (1) full integration with Excel 2003 (or higher) operating in a Windows environment; (2) intuitive graphical interface; (3) the ability to automatically test of the null hypothesis ("H 0 ") on the normal random variable on the basis of individual tests samples. Due to the first two requirements it was chosen implementation of applications based on the Excel spreadsheet in 2003 with the support code in Visual Basic for Applications, and a system of MS Office object libraries (libraries Visual Basic for Applications and Microsoft Office Object Library version 11.0). Application forms/dialog boxes with a comprehensive description of the buttons and functions associated with them, depending on the context and the currently executed thread in the application, provided a clear and intuitive graphical interface. All calculations required to perform the analyzes are conducted by the formula written on a permanent basis to work spreadsheet (invisible to the user). All input data required for the calculation of the iteration is copied to that worksheet to complete separation of data sources and applications.
The procedure in BAYNAL code consists of three main steps as follows:

- Step 1:

- provide initial data by the user, including the ability to select automatic operation;

- specify the file(s) to the data by the user (standard window opening set);

- open of the first file, activate the first sheet.

- Step 2:

- identify (or waiting indication) data to analyze the parameters of initial;

- analyse of the data indicated, any error handling specified data range;

- construct of the Shapiro-Wilk test for a random sample indicated, the term action in the event of non-compliance with the Shapiro-Wilk.

- Step 3:

- go to the next test/sheet/file in interactive mode or automatic;

- transit to the report generated by the resignation of the opening of the next set of statistical analysis ("Cancel" button in the dialog box to open files);

- close the source files (with the option: skip shift) and the creation of the report.

The main sheet of the BAYNAL code is the sheet "Start" (Field $1-\mathbf{P 1}$ ) as shown in Figure 2.

The BAYANAL code also includes reports previously performed statistical analyzes constituting of one sheet (P2). The names of these sheets are created automatically according to the scheme: "analyzed parameter name" and "date" 
(no year), and "time" of the analysis and formatted as shown in the P2. Sheets reports of the analyzes can move, copy and delete according to standard Excel commands. The work begins with an application of the button P3.
Pliocene "motley clay". These sediments of the Vistula valley form a glaciotectonic culmination. Above the Pliocene deposits there are preglacial (Eopleistocene) alluvial deposits consisting of quartz, gravel, sand and silt with lydites.

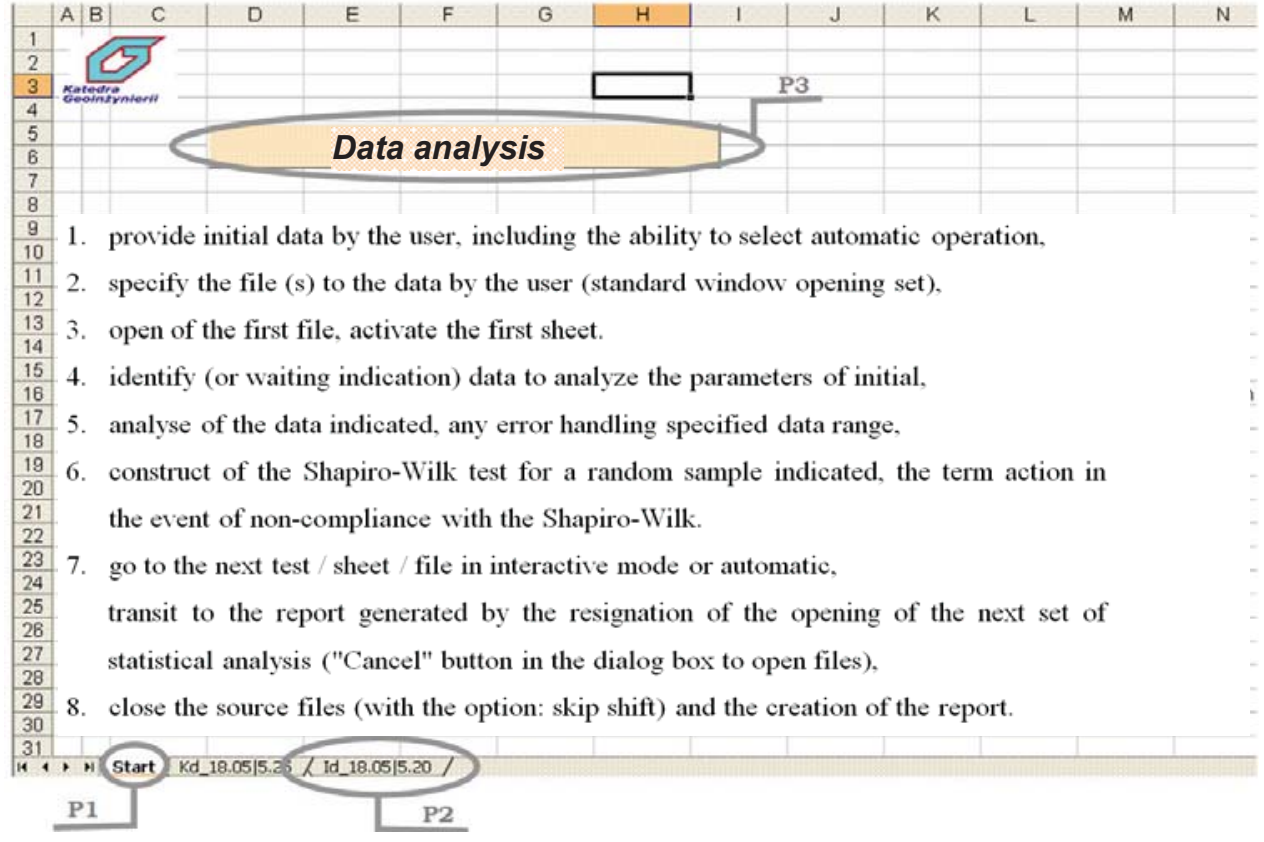

FIGURE 2. Main sheet of the BAYANAL code

\section{WULS-SGGW CAMPUS - GEOTECHNICAL CONDITIONS}

The Warsaw University of Life Sciences (SGGW) campus in the Ursynów district (Fig. 3) is located on upland of morainal origin (Garbulewski et al. 2016). To the east of the investigated area the upland drops with a steep incline to the so-called higher Praga terrace, one of three Pliocene terraces of the Vistula valley (Sarnacka 1976). The base of the valley consists mostly of Quaternary sediments as well as Tertiary, lacustrine
In the Ursynów upland, above the preglacial deposits, or directly on the lacustrine Pliocene clay, there is a series of SouthPolish Glaciation - boulder clay, glaciofluvial sediments, which form non-continuous layers. Over the sediments of the South-Polish Glaciation there is a thick formation, measuring 15 to $25 \mathrm{~m}$ of river-originated sediment from the Mazovian Interglacial. This consists mostly of sand and gravel. The upper part of this sediment is at a depth of between 10 and $20 \mathrm{~m}$ below ground level (Sarnacka 1992). In the region at the margin of a moraine 


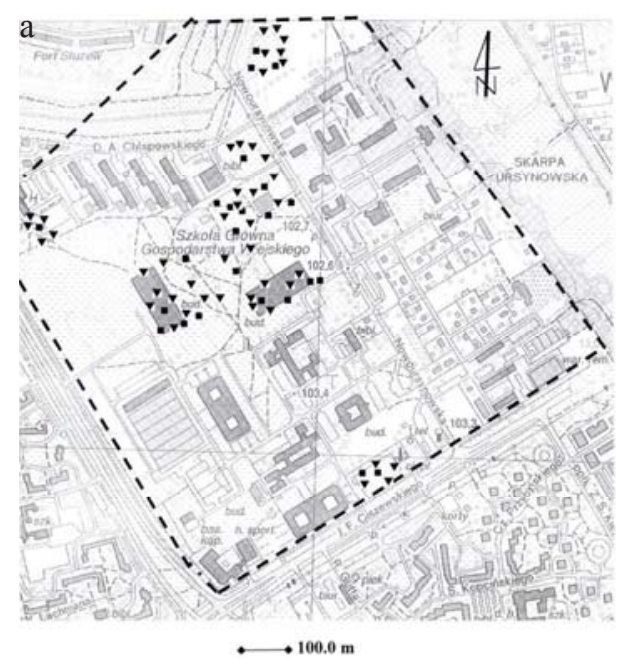

b

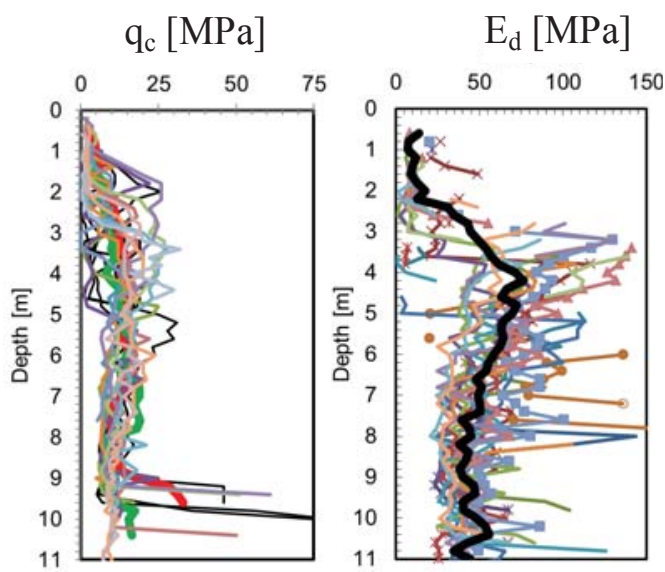

FIGURE 3. Map of the WULS-SGGW campus with locations of CPT ( $\boldsymbol{\nabla}$ ) and DMT ( $\mathbf{\bullet}$ ) tests (a); distribution of cone resistance $\left(q_{c}\right)$ of CPT tests and $\mathrm{E}_{\mathrm{D}}$ based on DMT (b)

plateau in Warsaw(Ursynów) such compositions form a continuous distinct layer consisting mainly of fine sand.

The geotechnical characteristics of grounds in the buildings designed in the frame of the WULS-SGGW Campus development were recognized by the interpretation of boring data (102 boreholes), CPT \& DMT tests (69 and 41 profiles, respectively) and comprehensive laboratory investigation. Analysing data gathered in the ground investigation report, five geotechnical layers were identified in the campus test site, including a layer of brown glacial boulder clay noted in this paper as Layer III (acc. to geotechnical classification sandy clay - saCL and sasiCL) of the Warta glaciation $\left({ }^{\mathrm{g}} \mathrm{Q}_{\mathrm{p}} \mathrm{W}\right)$, for which liquidity index values $\left(I_{L}\right)$ equal $0.0-0.11$ and a layer of grey glacial boulder clay of the Odra glaciation $\left({ }^{\mathrm{g}} \mathrm{Q}_{\mathrm{p}} \mathrm{O}\right)$, sandy clay with boulders as Layer IV, for which $I_{L}$ equal 0.0 -0.12 . Layer III was pointed out as layer with the most comfortable geotechnical conditions for foundation of the Cam- pus buildings, among them Building 34 analysed in this paper. The distribution of strength and deformation parameters for boulder clay were determined based on CPT and DMT investigation and common used in practice relationships (Fig. 3b).

The BAYANAL code (Garbulewski et al. 2009) was applied to determine the strength and deformation characteristic parameters of boulder clay (Layer III). Because of the availability of all test data both the classical and Bayesian approach could be used. Moreover the characteristic parameter were evaluated according to the Schneider formula. Taking into account all $q_{c}$ values from CPT tests and $E_{D}$ from DMT tests (Fig. 4) for boulder clay in Layer III the characteristic strength $\left(\tau_{f u}\right)$ and deformation $(M$ - constrained modulus) parameters were calculated as follows. From classical and Bayes approaches respectivelly: $\tau_{f u}=$ $=0.208 \mathrm{MPa}$ (average value)with standard deviation $s_{d} \pm 0.003 \mathrm{MPa} ; \tau_{f u}=0.213 \mathrm{MPa}$ 

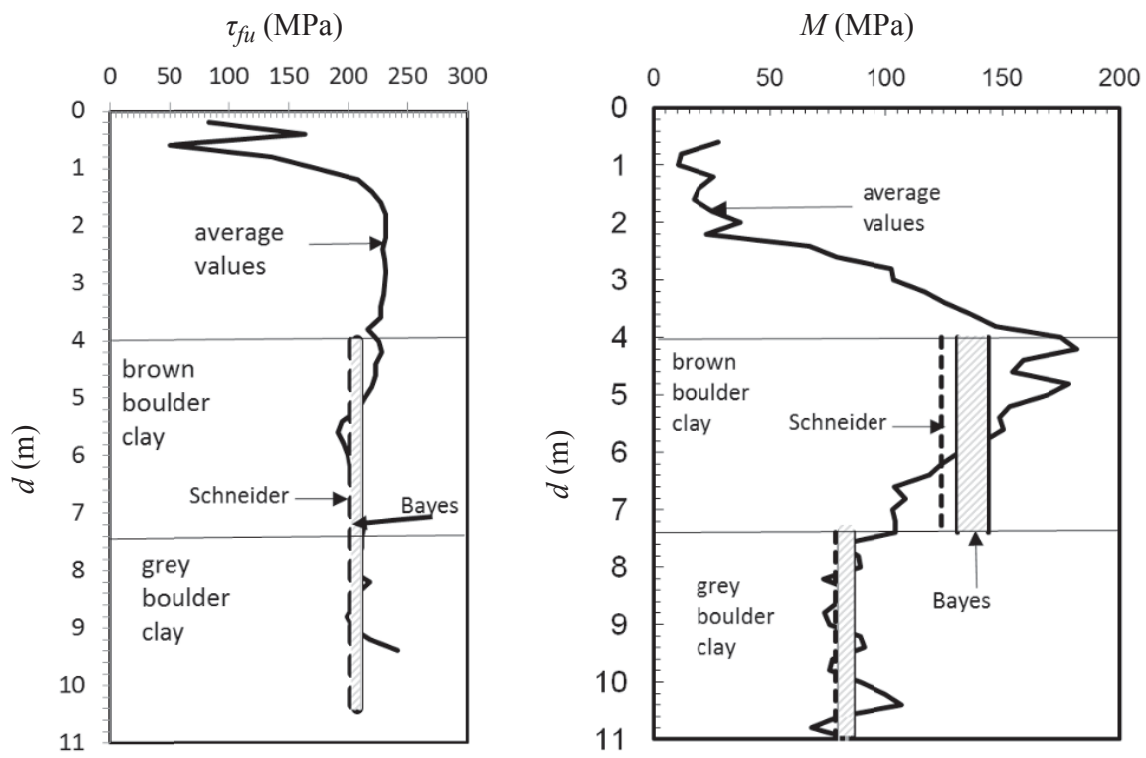

FIGURE 4. Characteristic values of undrained shear strength $-\left(\tau_{f u}\right)$ (a) and constrained modulus $M$ recommended for geotechnical design (b)

(with confidence coefficient equal 0.95); $M=137.4 \mathrm{MPa}$ (average value) with $s_{d} \pm 27 \mathrm{MPa} ; \mathrm{M}=150.4 \mathrm{MPa}$ (with confidence coefficient equal 0.95).

Based on the Schneider formula (2009): $\tau_{f u}=0.202 \mathrm{MPa}$ with standard deviation $s_{d} \pm 0.012 \mathrm{MPa} ; M=124.0 \mathrm{MPa}$ with standard deviation $s_{d} \pm 27 \mathrm{MPa}$.

\section{APPLICATION OF BAYANAL CODE - IMPACT OF TEST LOCATION}

The BAYANAL code was applied to determine the strength and deformation characteristic parameters of boulder clay (Layer III) in foundation of the Building 34 (Fig. 5). Taking into account $q_{c}$ values from CPT tests (six profiles) and $E_{D}$ from DMT tests (three profiles) for boulder clay in Layer III only for Building 34 the characteristic strength $\left(\tau_{f u}\right)$ and deformation $(M)$ parameters were as follows. From classical and Bayesian approaches: $\tau_{f u}=0.210 \mathrm{MPa}$ (average value) with standard deviation $s_{d} \pm 0.014 \mathrm{MPa}$ (classical approach) and $\pm 0.003 \mathrm{MPa}$ (average deviation in Bayesian approach at confidence coefficient $=0.95) ; M=136.2 \mathrm{MPa}$ (average value) with standard deviation $s_{d} \pm 30 \mathrm{MPa}$ (classical approach) and $\pm 7.5 \mathrm{MPa}$ (average deviation in Bayesian approach at confidence coefficient equal 0.95). Using the Schneider formula: $\tau_{f u}=0.203 \mathrm{MPa}$ with standard deviation $s_{d} \pm 0.014 \mathrm{MPa}$; $M=136.0 \mathrm{MPa}$ with standard deviation $s_{d} \pm 30.0 \mathrm{MPa}$.

In order to determine the impact of the test location on the characteristic values of geotechnical parameters $\left(\tau_{f u}\right.$ and $\left.M\right)$, a statistical analysis was carried out assuming the weight values of the parameters. To determine the weighted values of the parameters the following formula is proposed: 

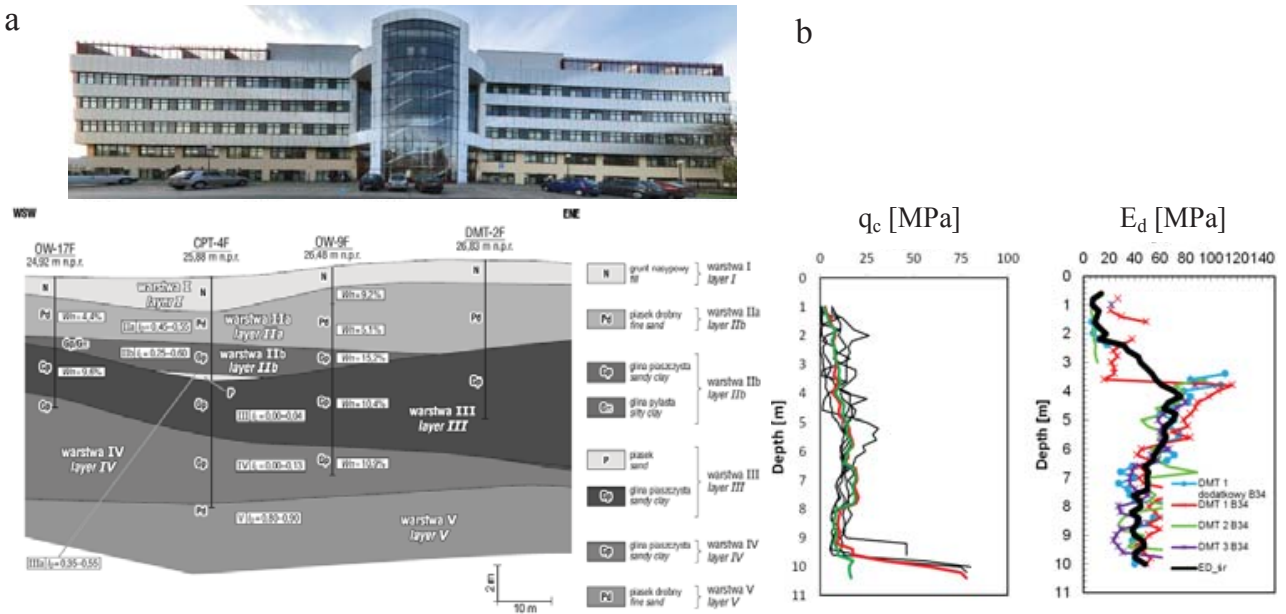

FIGURE 5. Typical geotechnical cross section for building 34: $w_{n}$ - moisture, $I_{D}$ - relative density, $I_{L}$ - plasticity index, $23.66 \mathrm{~m}$ - meter at Vistula level (a); distribution of cone resistance $q_{c}$ of CPT tests and $E_{D}$ based on DMT tests performed on the WULS-SGGW Campus (b)

$\bar{X}_{k}=\frac{\sum_{1}^{n} x_{i} \cdot w_{i}}{\sum_{1}^{n} w_{i}}$

where:

$\bar{X}_{k}$ - average weighted geotechnical parameter;

$x_{i}$ - value of the geotechnical parameter; $w_{i}$ - the weight of the geotechnical parameter as the ratio of the smallest distance from the object and the distance from the remaining tests.

The values of weights for the analyzed Building 34 (Fig. 6) were in the following range: $0.27-1.0$ for $\mathrm{CPT}$ and 0.43-1.0 for DMT. The smallest distance of CPT and DMT location from the design Building 34 were 20.77 and $31.25 \mathrm{~m}$ respectively, however the largest distance were 77.07 and $73.13 \mathrm{~m}$.

After introducing weights for parameters from the classical and Bayesian approaches the strength and constrained modulus are as follows: $\tau_{f u}=0.120 \mathrm{MPa}$ (average value) with standard deviation $s_{d} \pm 0.004 \mathrm{MPa}$ (classical approach) and $\pm 0.001 \mathrm{MPa}$ (average deviation in Bayesian approach at confidence coefficient $=0.95) ; M=89.0 \mathrm{MPa}$ (average value) with standard deviation $s_{d} \pm 19 \mathrm{MPa}$ (classical approach) and \pm 4.6 (average deviation in Bayesien approach at confidence coefficient $=0.95$ ) .

Using the Schneider formula: $\tau_{f u}=0.118 \mathrm{MPa}$ with standard deviation $s_{d} \pm 0.004 \mathrm{MPa} ; M=79.4 \mathrm{MPa}$ with standard deviation $s_{d} \pm 19.1 \mathrm{MPa}$.

Design undrained strength and constrained modulus were applied in the design of spread foundation for Building 34. Design soil parameters were determine using partial factors gathering in Table 1. Assuming the approach DA2* the results of design calculation using excel set were presented in Table 2 . 

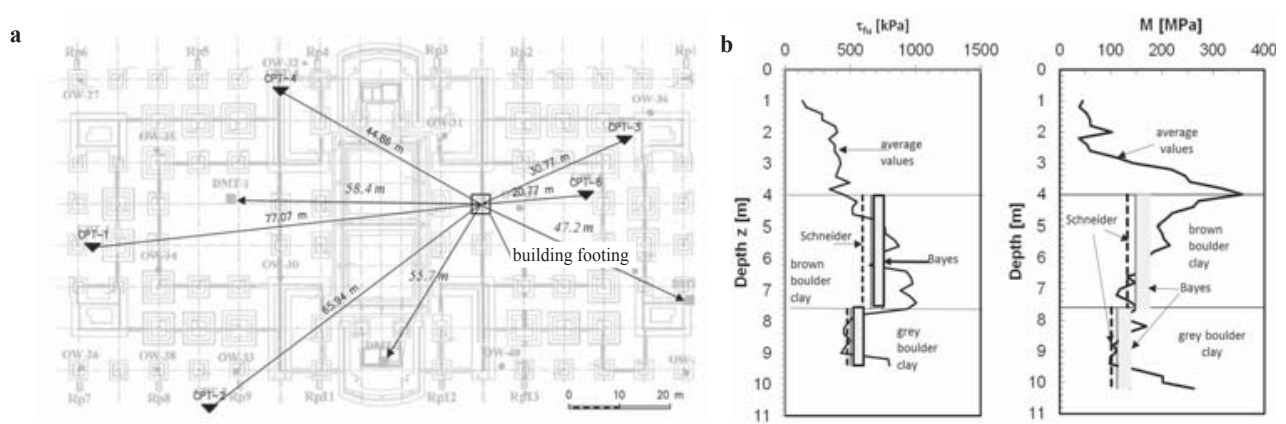

FIGURE 6. Location of CPT and DMT tests at WULS-SGGW Campus building 34 (a): characteristic values of undrained shear strength $\left(\tau_{f u}\right)$ and constrained modulus $(M)$ recommended for geotechnical design (b)

Considering the results of calculations the spread foundation with dimension of $2.70 \mathrm{~m}$ was recommended.

\section{CONCLUDING REMARKS}

In order to select the deformation and strength parameters for the weakest layer - boulder clay ( $\left.{ }^{\mathrm{g}} \mathrm{QpW}\right)$, occurring in the ground under the B34 WULS-SGGW building statistical analysis of in situ tests results was carried out. The analysis used indicator parameters $\left(q_{c}\right.$ and $E_{D}$ ) from 6 CPT soundings and 3 DMT tests. The mean value, the value with the specified confidence level of $95 \%$ and the standard deviation of the indicative parameters were determined using BAYANAL program. In order to take into account the location of in situ tests (test distances from the designed foundation) weights were introduced. The weights were defined as the ratio of the distance close to the foundation and the distance to the remaining soundings.

The values of the characteristic parameters $\left(\tau_{f u}, M\right)$ obtained for a single object (B34) are generally comparable with the values of the characteristic parameters obtained for the total area of the WULS-SGGW Campus. The strength and constrained modulus parameters of boulder clay recommended for design calculation (lower estimation) obtained using the classic and Bayes approaches and the Schneider formula are as follows respectively: $\tau_{f u k} 0.206,0.207$ and $0.203 \mathrm{MPa}, M_{k}$ 106, 129 and $121 \mathrm{MPa}$. The characteristic values of $\tau_{f u k}$ and $M_{k}$ obtained using the weight parameters are distinctly smaller: $\tau_{f u k}$ respectively 0.116 , 0.119 and $0.118 \mathrm{MPa} ; M_{k}$ respectively $70.0,84.4$ and 74.4. These parameter are too conservative taking into account the boulder clay states and preliminary measurements of building settlements.

It is important to underline that to determine the characteristic values of geotechnical parameters statistical methods should be used with caution. The BAYANAL code will be helpful in designing and therefore should be recommended to apply in geotechnical practice. 
TABLE 2. Results of design calculation for spread foundation (Building 34)

\begin{tabular}{|c|c|c|c|c|}
\hline \multirow{2}{*}{\multicolumn{2}{|c|}{ Geotechnical actions, partial factors and soil parameters }} & \multicolumn{3}{|c|}{$\mathrm{DA} 2: \mathrm{A} 1+\mathrm{M} 1+\mathrm{R} 2$} \\
\hline & & \multirow{2}{*}{$\begin{array}{l}B=2.75 \\
6035.00\end{array}$} & \multirow{2}{*}{$\begin{array}{l}B=2.60 \\
6035.00\end{array}$} & \multirow{2}{*}{$\begin{array}{l}B=2.70 \\
6035.00\end{array}$} \\
\hline $\begin{array}{l}V_{k}-\text { vertical characteristic permanent } \\
\text { load }(\mathrm{kN})\end{array}$ & & & & \\
\hline$L-$ length $=B-$ width $(\mathrm{m})$ & & 2.75 & 2.60 & 2.70 \\
\hline$H_{k}(\mathrm{kN})$ - horizontal force & & 0.00 & 0.00 & 0.00 \\
\hline$h-$ distance $(\mathrm{m})$ & & 0.0 & 0.0 & 0.0 \\
\hline$M_{k}=H_{k} \cdot h(\mathrm{kNm})$ & & 0.0 & 0.0 & 0.0 \\
\hline$d$-depth of the spead footing $(\mathrm{m})$ & & 1.0 & 1.0 & 1.0 \\
\hline$t-$ thickness of spread foundation (m) & & 1.0 & 1.0 & 1.0 \\
\hline$\gamma_{k}^{\prime}-$ soil bulk weight $\left(\mathrm{kN} / \mathrm{m}^{3}\right)$ & & 20.0 & 20.0 & 20.0 \\
\hline$\gamma_{d}^{\prime}=\gamma_{k}^{\prime} / \gamma_{M}\left(\mathrm{kN} / \mathrm{m}^{3}\right)$ & & 20.0 & 20.0 & 20.0 \\
\hline $\begin{array}{l}\varphi^{\prime}{ }_{k}-\text { characteristic angle of shearing } \\
\text { resistance }\left({ }^{\circ}\right)\end{array}$ & & 35 & 35 & 35 \\
\hline $\begin{array}{l}\varphi^{\prime}{ }_{k}-\text { characteristic angle of shearing } \\
\text { resistance }(\mathrm{rad})\end{array}$ & & 0.611 & 0.611 & 0.611 \\
\hline $\operatorname{tg} \varphi_{k}^{\prime}$ & & 0.700 & 0.700 & 0.700 \\
\hline$\varphi_{d}^{\prime}-\operatorname{arctg}\left(\operatorname{tg} \varphi_{k}^{\prime} / \gamma_{M}\right)(\mathrm{rad})$ & & 0.611 & 0.611 & 0.611 \\
\hline$\left.\varphi_{d}^{\prime}{ }^{\circ}{ }^{\circ}\right)$ & & 35.00 & 35.00 & 35.00 \\
\hline $\operatorname{tg} \varphi_{d}^{\prime}$ & & 0.700 & 0.700 & 0.700 \\
\hline $\operatorname{ctg} \varphi_{d}^{\prime}$ & & 1.428 & 1.428 & 1.428 \\
\hline $\sin \varphi_{d}^{\prime}$ & & 0.574 & 0.574 & 0.574 \\
\hline$c_{k}^{\prime}(\mathrm{kPa})$ & & 10.0 & 10.0 & 10.0 \\
\hline $\mathrm{c}_{\mathrm{d}}^{\prime}=\mathrm{c}_{\mathrm{k}}^{\prime} / \gamma_{M}(\mathrm{kPa})$ & & 10.0 & 10.0 & 10.0 \\
\hline$\gamma_{\text {bet }}-$ unit concrete weight $\left(\mathrm{kN} / \mathrm{m}^{3}\right)$ & & 24.0 & 24.0 & 24.0 \\
\hline$V_{B}=B \cdot L \cdot d\left(\mathrm{~m}^{3}\right)$ & & 7.56 & 6.76 & 7.29 \\
\hline$G_{k}=V_{k}+\gamma_{b e t} \cdot V_{B}(\mathrm{kN})$ & & 6217 & 6197 & 6210 \\
\hline$Q_{1 k}=V_{k}-$ vertical load variable $(\mathrm{kN} / \mathrm{m})$ & & 750 & 750 & 750 \\
\hline $\begin{array}{l}Q_{2 k}=H_{k}-\text { horizontal load variable } \\
(\mathrm{kN} / \mathrm{m})\end{array}$ & & 0.0 & 0.0 & 0.0 \\
\hline$\Psi_{O}-$ safety partial factor & & 0.7 & 0.7 & 0.7 \\
\hline$V_{d}=\gamma_{G} \cdot G_{k}+\gamma_{Q} \cdot Q_{1 k}(\mathrm{kN})$ & & 9518 & 9491 & 9359 \\
\hline$H_{d}=\Psi_{O} \cdot \gamma_{Q} \cdot Q_{2 k}(\mathrm{kN})$ & design actions & 0.00 & 0.00 & 0.00 \\
\hline$M_{d}=H_{d} \cdot h(\mathrm{kNm})$ & & 0.00 & 0.00 & 0.00 \\
\hline$e_{B}=\left(\gamma_{G} \cdot Q_{2 k} \cdot h\right) / V_{d}=M_{d} / V_{d}(\mathrm{~m})$ & & 0.00 & 0.00 & 0.00 \\
\hline verification $-B / 3-e_{B}>0$ & & 0.92 & 0.87 & 0.90 \\
\hline$B^{\prime}=B-2 \cdot e(\mathrm{~m})$ & & 2.75 & 2.60 & 2.70 \\
\hline$L^{\prime}=B^{\prime}(\mathrm{m})$ & & 2.75 & 2.60 & 2.70 \\
\hline
\end{tabular}




\begin{tabular}{|c|c|c|c|c|}
\hline \multirow{2}{*}{\multicolumn{2}{|c|}{ Geotechnical actions, partial factors and soil parameters }} & \multicolumn{3}{|c|}{$\mathrm{DA} 2: \mathrm{A} 1+\mathrm{M} 1+\mathrm{R} 2$} \\
\hline & & \multirow{2}{*}{$\begin{array}{c}B=2.75 \\
7.56\end{array}$} & \multirow{2}{*}{$\begin{array}{c}B=2.60 \\
6.76\end{array}$} & \multirow{2}{*}{$\begin{array}{c}B=2.70 \\
7.29\end{array}$} \\
\hline$A^{\prime}=B^{\prime} \cdot L^{\prime}=A\left(\mathrm{~m}^{2}\right)$ & & & & \\
\hline$B^{\prime} / L^{\prime}(-)$ & & 1.000 & 1.000 & 1.000 \\
\hline$m_{B}=\left[2+\left(B^{\prime} / L^{\prime}\right)\right] /\left[1+\left(B^{\prime} / L^{\prime}\right)\right]$ & & 1.500 & 1.500 & 1.500 \\
\hline$e^{\pi \operatorname{tg} \varphi^{\prime}} d$ & & 9.023 & 9.023 & 9.023 \\
\hline $\operatorname{tg}^{2}\left(45^{\circ}+\varphi_{d}^{\prime} / 2\right)$ & & 3.690 & 3.690 & 3.690 \\
\hline$N_{q}=e_{d}^{\pi t g \varphi^{\prime}} \cdot \operatorname{tg}^{2}\left(45^{\circ}+\varphi_{d}^{\prime} / 2\right)$ & & 33.30 & 33.30 & 33.30 \\
\hline$N_{c}=\left(N_{q}-1\right) \cdot \operatorname{ctg} \varphi_{d}^{\prime}$ & & 46.12 & 46.12 & 46.12 \\
\hline$N \gamma=2 \cdot\left(N_{q}-1\right) \cdot \operatorname{tg} \varphi_{d}^{\prime}$ & & 45.23 & 45.23 & 45.23 \\
\hline$s_{q}=1+\left(B^{\prime} / L^{\prime}\right) \cdot \sin \varphi_{d}^{\prime}$ & & 1.57 & 1.57 & 1.57 \\
\hline$s_{c}=\left(s_{q} \cdot N_{q}-1\right) /\left(N_{q}-1\right)$ & & 1.59 & 1.59 & 1.59 \\
\hline$s_{\gamma}=1-0,3 \cdot\left(B^{\prime} / L^{\prime}\right)$ & & 0.70 & 0.70 & 0.70 \\
\hline$i_{q}=\left[1-H_{d} /\left(V_{d}+A^{\prime} \cdot \mathrm{c}^{\prime} \cdot \operatorname{ctg} \varphi_{d}^{\prime}\right)\right]^{\wedge} m_{B}$ & & 1.0 & 1.0 & 1.0 \\
\hline$i_{c}=i_{q}-\left(1-i_{q}\right) /\left(N_{c} \cdot \operatorname{tg} \varphi_{d}^{\prime}\right)$ & & 1.0 & 1.0 & 1.0 \\
\hline $\begin{array}{l}i_{\gamma}=\left[1-H_{d} /\left(V_{d}+A^{\prime} \cdot \mathrm{c}^{\prime} \cdot \operatorname{ctg} \varphi_{d}^{\prime}\right)\right]^{\wedge} \\
\left(1+m_{B}\right)\end{array}$ & & 1.0 & 1.0 & 1.0 \\
\hline$b_{c}=b_{q}=b_{\gamma}$ & & 1.0 & 1.0 & 1.0 \\
\hline$q^{\prime}=\gamma_{d}^{\prime} \cdot \mathrm{d}\left[\mathrm{kN} / \mathrm{m}^{2}\right]$ & & 20.0 & 20.0 & 20.0 \\
\hline $\begin{array}{l}R_{k}=A^{\prime} \cdot\left(c_{d}^{\prime} \cdot N_{c} \cdot s_{c} \cdot b_{c} \cdot i_{c}+q^{\prime} \cdot N_{q} \cdot s_{q} \cdot\right. \\
\left.\cdot b_{q} \cdot i_{q}+0,5 \cdot \gamma^{\prime} \cdot B^{\prime} \cdot N_{\gamma} \cdot s_{\gamma} \cdot b_{\gamma} \cdot i_{\gamma}\right)\end{array}$ & & 20060 & 17610 & 19221 \\
\hline$R_{d}=R_{k} / \gamma_{R ; v}(\mathrm{kN})$ & & 14328 & 12578 & 13730 \\
\hline \multirow{4}{*}{$\begin{array}{l}\text { Global safety factor } \\
O F S=R / V\end{array}$} & $R_{k} / V_{k}$ & 2.9 & 2.5 & 2.8 \\
\hline & $R_{k} / V_{d}$ & 2.1 & 1.9 & 2.1 \\
\hline & $R_{d} / V_{d}$ & 1.5 & 1.3 & 1.5 \\
\hline & $R_{d} / V_{k}$ & 2.1 & 1.8 & 2.0 \\
\hline \multicolumn{5}{|c|}{ Undrained conditions } \\
\hline$c_{u}(\mathrm{kPa})$ & 203 & 206 & 207 & 203 \\
\hline$c_{u d}=c_{u} / \gamma_{M}(\mathrm{kPa})$ & 203 & 206 & 207 & 203 \\
\hline$\left.R_{k}=A^{\prime}(\pi+2) c_{u d} \cdot b_{c} \cdot s_{c} \cdot i_{c}+q^{\prime}\right)(\mathrm{kN})$ & 9623 & 8727 & 9456 & 9623 \\
\hline$R_{d}=R_{k} / \gamma_{R ; v}(\mathrm{kN})$ & 9623 & 8727 & 9456 & 9623 \\
\hline \multirow{5}{*}{$\begin{array}{l}\text { DA2* } \\
\text { Global safety factor } \\
O F S=R / V\end{array}$} & $R_{k} / V_{k}$ & 1.4 & 1.3 & 1.4 \\
\hline & $R_{k} / V_{d}$ & 1.0 & 0.9 & 1.0 \\
\hline & $R_{d} / V_{d}$ & 1.0 & 0.9 & 1.0 \\
\hline & $R_{d} / V_{k}$ & 1.4 & 1.3 & 1.4 \\
\hline & $V_{k} / R_{k}$ & 0.7 & 0.8 & 0.7 \\
\hline
\end{tabular}


TABLE 2. cont.

\begin{tabular}{|l|l|c|c|c|}
\hline \multirow{2}{*}{ Geotechnical actions, partial factors and soil parameters } & \multicolumn{3}{|c|}{$\mathrm{DA} 2: \mathrm{A} 1+\mathrm{M} 1+\mathrm{R} 2$} \\
\cline { 3 - 5 } & $B=2.75$ & $B=2.60$ & $B=2.70$ \\
\hline \multirow{3}{*}{ Utilization factor } & $V_{d} / R_{k}$ & 1.0 & 1.1 & 1.0 \\
\cline { 2 - 5 } & $V_{d} / R_{d}$ & 1.0 & 1.1 & 1.0 \\
\cline { 2 - 5 } & $V_{k} / R_{d}$ & 0.7 & 0.8 & 0.7 \\
\hline
\end{tabular}

\section{REFERENCES}

ALÉN C.G. 1998: On probability in geotechnics. Random calculation models exemplified on slope stability analysis and ground-superstructure interaction. Doctoral thesis, Chalmers University of Technology, Göteborg.

ALÉN C.G., SÄLLFORS G.B. 1999: Uncertainties in modeling of soil properties. Proceedings of the EC SMGE: Geotechnical Engineering for Transportation Infrastructure, Balkema, Rotterdam.

BOND A.J., HARRIS A.J. 2008: Decoding Eurocode 7. Taylor and Francis, London.

EN 1997-1:2007. Eurocode 7. Geotechnical design. Part 1. General rules.

EN 1997-2:2007. Eurocode 7. Geotechnical design. Part 2. Ground investigation and testing.

FRANK R., BAUDUIN C., DRISCOLL R., KAVVADAS M., KREBS OVESEN N., ORR T.L.L., SCHUPPENER B. 2004: Designers' Guide to EN 1997-1, Eurocode 7: Geotechnical design Part 1: General rules. Thomas Telford, London.

GARBULEWSKI K., FALKOWSKI T., RABARIJOELY S., OSTROWSKI P. 2016: Geomorphological analysis in soil profile assessment of the margin of Warsaw morainic plateau in Ursynów. Ann. Warsaw Univ. Life Sci. - SGGW, Land Reclam. 48 (4): 353-363.

GARBULEWSKI K., JABŁONOWSKI S., RABARIJOELY S. 2009: Advantage of Bayesian approach to geotechnical designing. Ann. Warsaw Univ. Life Sci. - SGGW, Land Reclam. 41 (2): 83-93.
ORR T.L.L. (Ed.) 2005: Proceedings of International Workshop on Evaluation of Eurocode 7. Department of Civil, Structural and Environmental Engineering, Trinity College, Dublin.

PIECZYRAK J. 2009: Stany graniczne i warunki obliczeniowe $\mathrm{w}$ geotechnice. Materiały XXIV Ogólnopolskich Warsztatów Pracy Projektanta Konstrukcji, 17-20.03.2009, Wisła, Vol. 1: 247-270.

POPIELSKI P., DĄBSKA A. 2012: Analiza granicznych odkształceń konstrukcji i przemieszczeń fundamentów według PN-EN 1997-1:2008 w świetle innych norm. Inż. Bud. 68 (1): 33-39.

SARNACKA Z. 1976: Objaśnienia do szczegółowej mapy geologicznej Polski 1:50000 [Explanations to the detailed geological map of Poland 1:50000]. Piaseczno. Państwowy Instutut Geologiczny, Warszawa.

SARNACKA Z. 1992: Stratygrafia osadów czwartorzędowych Warszawy i okolic [Stratigraphy of the quaternary sediments in Warsaw and neighborhood]. Prace PIG 138: 36.

SCHNEIDER H.R. 1990: Die Wahl der Baugrundkennwerte. Anwendung der neuen Tragwerksnormen des SIA im Grundbau, Mitteilungen der Schweizerischen Gesell-schaft für Boden und Felsmechanik, Zürich.

SCHNEIDER H.R. 1997: Definition and determination of characteristic soil properties. Proceedings of the 16th International Conference on Soil Mechanics and Geotechnical Engineering, Hamburg, Balkema, Rotterdam. 
SCHNEIDER H.R. 2010: Characteristic Soil Properties for EC7: Influence of quality of test results and soil volume involved. Proceedings of 14th Danube - European Conference on Geotechnical Engineering, 02.06.2010, Bratislava.

SCHNEIDER H.R., FITZE P. 2009: Charakteristische Baugrundwerte: Erfahrung, Versuchswerte und Statistik. Herbsttagung SBGF, 06.11.2009, EPFL, Lausanne.

SCHUPPENER B., SIMPSON B., ORR T.L.L., FRANK R., BOND A.J. 2009: Loss of static equilibrium of a structure - definition and verification of limit state EQU. Proceedings of 2nd International Symposium on Geotechnical Safety and Risk, 11-12.06.2009, Gifu.

PN-B-03020:1981. Grunty budowlane. Posadowienie bezpośrednie budowli. Obliczenia staytyczne i projektowanie.

UZIELLI M. 2008: Statistical analysis of geotechnical data. In: A-B. Huang, P.W. Mayne (Eds.). Geotechnical and Geophysical Site Characterization. Taylor \& Francis Group, London.

Streszczenie: Parametry wytrzymatościowe i odksztatceniowe iłów zwatowych do projektowania budynków w strefie krawędziowej wysoczyzny morenowej w Warszawie. Dobór parametrów geotechnicznych do sprawdzenia stanów granicznych w projektach geotechnicznych jest powszechnie uważany za jedno z najważniejszych i jednocześnie trudnych zadań inżynierskich. Zgodnie ze standardami Eurokodu 7 dobór ten powinien być wykonany w trzech etapach. Drugi z etapów, a mia- nowicie określenie wartości charakterystycznych, wymaga rozważnego oszacowania przy zastosowaniu metod statystycznych, nawet podejścia bayesowskiego, jak pokazano w niniejszym artykule. W artykule przedstawiono proces doboru parametrów wytrzymałościowych i odkształceniowych z badań CPT i DMT dla iłów zwałowych występujących na terenie kampusu SGGW (Warszawa). Warstwa iłów została wybrana do zlokalizowania fundamentów projektowanych budynków akademickich. W doborze parametrów charakterystycznych przy zastosowaniu programu numerycznego BAYANAL uwzględniono rozkład przestrzenny wartości wytrzymałości na ścinanie bez odpływu i modułu ściśliwości. Szczególną uwagę zwrócono na wpływ wynikający z lokalizacji sondowań in situ w różnych odległościach od obiektów projektowych. Na koniec przedstawiono wnioski, w tym opinię na temat roli zakresu i rozmieszczenia punktów badawczych w projektowaniu geotechnicznym.

Stowa kluczowe: obliczeniowe parametry iłów, analiza statystyczna, podejście bayesowskie, projektowanie geotechniczne, Eurokod 7

$M S$ received 10.02.2018

MS accepted 26.03.2018

\section{Authors' address:}

Simon Rabarijoely

Katedra Geoinżynierii

Wydział Budownictwa i Inżynierii Środowiska

Szkoła Główna Gospodarstwa Wiejskiego

w Warszawie

ul. Nowoursynowska 166, 02-787 Warszawa

Poland

e-mail: simon_rabarijoely@sggw.pl 